\section{SOI: 1.1/TAS DOI: 10.15863/TAS \\ International Scientific Journal Theoretical \& Applied Science}

p-ISSN: $2308-4944$ (print)

e-ISSN: 2409-0085 (online)

Year: 2015

Issue: 04

Volume: 24

Published: $30.04 .2015 \quad$ http://T-Science.org

SECTION 32. Jurisprudence.

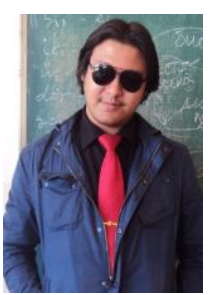

Yernar Sailaubekovich Shalkharov

Doctor of Philosophy in law

Department of Strategic Planning of Scientific Research Developments in Applied Sector Law department of International Kazakh Turkish University by name of A.Yasavi, Kazakhstan yernar_shalkharov@bk.ru

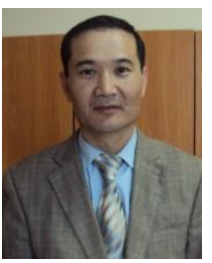

Kairat Amanzholovich Turlybekov Master of law science, senior lecturer Department of Strategic Planning of Scientific Research Developments in Applied Sector, Law department of International Kazakh Turkish University by name of A.Yasavi, Kazakhstan

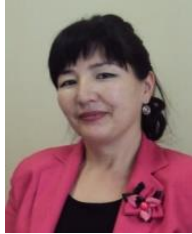

Akmaral Nurmahanovna Esenzholova Master of law science, $\mathrm{PhD}$, associated professor Department of Strategic Planning of Scientific Research Developments in Applied Sector, Law department of

International Kazakh Turkish University by name of A.Yasavi, Kazakhstan

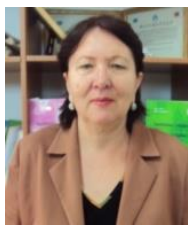

Klara Rakhimovna Hasanova

Senior Lecturer in law science Department of Strategic Planning of Scientific Research Developments in Applied Sector, Law department of International Kazakh Turkish University by name of A.Yasavi, Kazakhstan

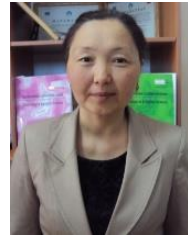

Liazzat Akimzhanovna Abubakirova Candidate of law science Department of Strategic Planning of Scientific Research Developments in Applied Sector, Law department of International Kazakh Turkish University by name of A.Yasavi, Kazakhstan

\title{
LEGAL CONCEPTION OF INTELLECTUALPROPERTY OBJECTS INSURANCE AND ESTIMATION BY THE WAY OF MULTIPLICITY ELEMENTS OF FINE ART ALGORITHM
}

\begin{abstract}
Today conception of intellectual property is extremely high developing direction. Consequently, it is because of the high percentage of the whole art popularity all over the world. Thus, it will be point out right at the moment that fine art is increasing in price, especially because of it progression in the market economy area. However, there are some issues which give problems to such direction as intellectual property in fine art section. Nevertheless, there were found nice solution to this problem as multiplicity elements of fine art algorithm.

Key words: estimation, insurance multiplicity elements, fine art algorithm, population, civil rules, democratic society, disputes, art, capacity.

Language: English

Citation: Shalkharov YS, Turlybekov KA, Esenzholova AN, Hasanova KR, Abubakirova LA (2015) LEGAL CONCEPTION OF INTELLECTUALPROPERTY OBJECTS INSURANCE AND ESTIMATION BY THE WAY OF MULTIPLICITY ELEMENTS OF FINE ART ALGORITHM. ISJ Theoretical \& Applied Science 04 (24): 269-271.

Soi: http://s-o-i.org/1.1/TAS*04(24)49 Doi: crossef http://dx.doi.org/10.15863/TAS.2015.04.24.49

To date all over the world there is a certain dynamics of development of culture, especially in terms of regulation of objects of art. At this time, in the Republic of Kazakhstan the number of

contentious issues in this direction insignificantly. However, craving for art among the population is growing both among middle and low secured segments of the population as well as among high
\end{abstract}




$\begin{array}{llr}\text { Impact Factor ISRA }(\text { India) }=\mathbf{1 . 3 4 4} & \text { Impact Factor JIF } & =\mathbf{1 . 5 0 0} \\ \text { Impact Factor ISI (Dubai, UAE) }=\mathbf{0 . 8 2 9} & \text { Impact Factor SIS (USA) } & =\mathbf{0 . 9 1 2} \\ \text { based on International Citation Report (ICR) } & \text { Impact Factor PИHЦ (Russia) }=\mathbf{0 . 1 7 9} \\ \text { Impact Factor GIF (Australia) }=\mathbf{0 . 3 5 6} & \text { Impact Factor ESJI (KZ) } & =\mathbf{1 . 0 4 2}\end{array}$

secured segments of the population, thereby encouraging the emergence of a large number of disputes over the data estimates of various elements of the works. There are many different theories providing an opportunity state to evaluate the picture appropriately, however, at the normative level, the activity is not fixed, which gives great privileges to many non commercial organizations [1]. Evaluation of a product is made, as a rule, based on internal beliefs of experts, though in legal state, these objects have to be evaluated in accordance with the set standards prescribed in the specific regulatory sources. As a consequence, the following question arises about how to properly arrange insurance for this object in the event of circumstances of unforeseen force. Such issues are usually not covered by insurance legislation in detail, which leads do not abilities to operate in applied using [2].

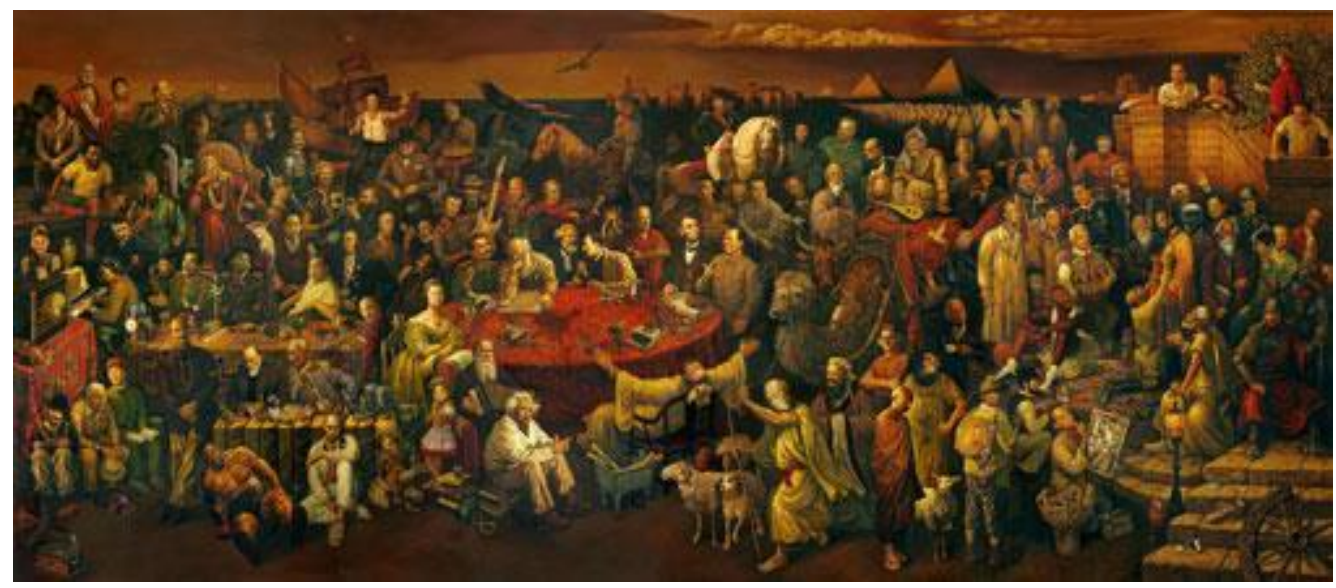

Picture 1 - Lui Ikart - Nouveau.

Meanwhile, the civil legislation of the Republic of Kazakhstan provides certain provisions for the detailed identification of the object of art. So, for example, in subpart 1 part 2 Article 961 of the Civil Code of the Republic of Kazakhstan works of science, literature and art are classified as the result of intellectual creative activity, which in turn guarantees the author is absolutely any non property and property rights without any direct or indirect restrictions on the basis part 1 Article 963 of the Civil Code of the Republic of Kazakhstan [3]. In such a way authors of these works objects of fine art possess a unique right to establish a base for the formation of the assessed value of the objects based on the calculation of estimated items based on the current legislation of the Republic of Kazakhstan at all levels of the legal hierarchy, a higher power which has part 4 article 26 the Constitution of of the Republic of Kazakhstan, according to which, the free use of his property for any legal business activity is the legal capacity of every citizen guaranteed by the Constitution of the Republic of Kazakhstan. Also in Part 1 Article 20 of the Constitution of the Republic of Kazakhstan shall be guaranteed the freedom of creativity and even more so by virtue the factor of increase the level of democracy in the state, this area is under the protection of the state [4]. In such a way a person can be the author of several elements evaluated and insured individually. Thus, in accordance with Part 2 Article 964 of the Civil Code of the Republic of Kazakhstan, "the owner an exclusive right under copyright may transfer this right to another person in whole or in part, to allow use intellectual property objects and dispose of it in any other way, unless it is contradict the rules of the present Code and other legislative acts. This concept gives the owner of a work of art to calculate amount of itself intellectual property object, proceeding from cost used in these elements separately, which algorithmically increases the cost of this works of art at the rate of multiple used in this products of the elements of other works of art in the framework of agreements with the authors of these elements. In such a way in the state there is necessity of creation certain types of documents having a normative character, classifies works of art according to the regimented list of evaluated elements formulated on the basis of conducted legal research, backed by a powerful statistical processing in order to identify more authentic and using the passed judicial precedents, necessary to adapt of this document in applied production [5]. Hypothetically, this policy would enable the State at the macroeconomic level to become a worthy participant producers works of art on the world scene, gradually increasing the chances of the presentation of paintings in the world galleries [6]. Consequently by supporting this concept the Republic of Kazakhstan can perform two types of 
external state activities at a high level, namely, to increase the chances of economic stability in the sector of sales of fine art, to promote ethnic interests in the international community, representing the Republic of Kazakhstan as one of the countries of Central Asia, which has rich creative potential. Parallel, in the internal state level, this concept will allow reserving the problem of unemployment, attracting unemployed segments of the population to engage in painting, to evaluate the information as the results of the state level, to insure them and use outlines and sketches as elements for paintings of high-level [7]. In practice, this concept historically has already been used in countries such as Florence, Venice, Naples, Macedonia [8].
Summing up the results can assume that in the next decade, this policy is quite feasible the Republic of Kazakhstan at the legislative level in the field of applied production as legislatively in the Republic has all the normative elements in the civil and international law, allowing to maneuver freely, conduct research, to build hypotheses and make the results in the industry. This is especially more actual that the elements of national ornaments and designs have more and more popular in the world practice. On the territory of the former Soviet states this concept has no analogues and in the Central Asian region is provided for the first time.

\section{References:}

1. William M. Landes, Daniel B. Levine (2014) Chapter 7 The Economic Analysis of Art Law Review Article Handbook of the Economics of Art and Culture, Volume 1, 2014, Pages 211 251.

2. Dean Keith Simonton (2014) Chapter 2 Creative Genius in Literature, Music, and the Visual Arts Handbook of the Economics of Art and Culture, Volume 2, 2014, Pages 15-48.

3. (2015) The Civil Code Of The Republic Of Kazakhstan.

4. (2015) The Constitution Of The Republic Of Kazakhstan.

5. S. Lysytsia (2011) 26 Law regulation of ART in Ukraine Reproductive BioMedicine Online, Volume 22, Supplement 2, March 2011, Page S104.
6. Xin Liu, Jianhong(Cecilia) Xia, Graeme Wright, Lesley Arnold (2014) A state of the art review on High Water Mark (HWM) determination Review Article Ocean \& Coastal Management, Volume 102, Part A, December 2014, Pages 178-190.

7. Jean-Philippe Platteau, Zaki Wahhaj (2014) Chapter 22 - Strategic Interactions Between Modern Law and Custom Handbook of the Economics of Art and Culture, Volume 2, 2014, Pages 633-678.

8. Urvashi Prasad Jha, Swasti (2008) The Law, Science and Art of Consent-A Gynaecologist's Approach Original Research Article Apollo Medicine, Volume 5, Issue 1, March 2008, Pages 48-60. 